\title{
EFEKTIVITAS PROGRAM KEMITRAAN PT. KAI DAOP 2 BANDUNG DALAM PENGEMBANGAN USAHA KECIL DAN MENENGAH
}

\author{
Oleh: \\ Syammas Perdana, Eva Nuriyah Hidayat, \& Sahadi Humaedi
}

\begin{abstract}
ABSTRAK: Kemiskinan adalah keadaan dimana terjadi ketidakmampuan untuk memenuhi kebutuhan dasar seperti makanan, pakaian, tempat berlindung, pendidikan, dan kesehatan. Kemiskinan dapat disebabkan oleh kelangkaan alat pemenuh kebutuhan dasar, ataupun sulitnya akses terhadap pendidikan dan pekerjaan. Kemiskinan merupakan masalah global. Sebagian orang memahami istilah ini secara subyektif dan komparatif, sementara yang lainnya melihatnya dari segi moral dan evaluatif, dan yang lainnya lagi memahaminya dari sudut ilmiah yang telah mapan. Kemiskinan dipahami dalam berbagai cara. Pemahaman utamanya mencakup:

Gambaran kekurangan materi, yang biasanya mencakup kebutuhan pangan sehari-hari, sandang, perumahan, dan pelayanan kesehatan. Kemiskinan dalam arti ini dipahami sebagai situasi kelangkaan barang-barang dan pelayanan dasar. Gambaran tentang kebutuhan sosial, termasuk keterkucilan sosial, ketergantungan, dan ketidakmampuan untuk berpartisipasi dalam masyarakat. Hal ini termasuk pendidikan dan informasi. Keterkucilan sosial biasanya dibedakan dari kemiskinan, karena hal ini mencakup masalah-masalah politik dan moral, dan tidak dibatasi pada bidang ekonomi.Gambaran kemiskinan jenis ini lebih mudah diatasi daripada dua gambaran yang lainnya.

Pemberdayaan sebagai strategi pengentasan kemiskinan harus menjadi proses multidimensi dan multisegi yang memobilisasi sumberdaya dan kapasitas masyasrakat. Dalam hal ini, pemberdayaan tidak lagi menjadi sesuatu yang teoritis melainkan menjadi alat untuk memutar-balikkan proses pemiskinan. Kelompok masyarakat miskin amat rentan karena mereka tidak memiliki sistem penyangga kehidupan yang memadai. Pemberdayaan ini dapat dijadikan sebagai media dalam menyuarakan kepentingan, prioritas dan alternatif terhadap solusi yang berkaitan dengan masalah., sehingga dalam prosesnya terdapat partisipasi oleh warganya.
\end{abstract}

Kata kunci: Kemiskinan, Pemberdayaan, Pemecahan masalah, dan Kapasitas masyarakat.

ABSTRACT: Poverty is a State of wherein case the inability to meet basic needs such as food, clothing, shelter, education and health. Poverty can be caused by a scarcity of basic needs, locally abundant tools or difficulty of access to education and jobs. Poverty is a global problem. Most people understand the term is subjective and comparative basis, while others see it in terms of moral and evaluative, and others understood it from the established scientific angle. Poverty is understood in different ways. Primary insight covers:

Description of material deficiencies, which usually include the daily food needs, clothing, housing, and health services. Poverty in this sense is understood as a situation of scarcity of goods and basic services. An overview of social needs, including social keterkucilan, dependency, and the inability to participate in the community. This includes education and information. Social Keterkucilan is usually distinguished from poverty, because it covers the issues of politics and morals, and not restricted to the economic sphere. This type of poverty figures are easier to overcome than the two other picture. 
Empowerment as poverty reduction strategy should be the process of multisegi multidimensional and that the resources and mobilizing masyasrakat capacity. In this case, empowerment be no longer being theoretical but be an instrument for memutar-balikkan the process of impoverishment of the .A group of poor people highly susceptible because they have no buffer system adequate life.The empowerment of this can be used as the media in voicing interests, priorities and alternative for a solution with regard to the problem, in the process so that there are participation by citizens .

Key words: poverty, empowerment, the solution of a problem, and capacity of the community.

\section{PENDAHULUAN}

Di era globalisasi sekarang ini, dunia telah memasuki babak baru masyarakat global, yakni babak baru dari suatu era masyarakat yang semakin universal dan modern. Sekarang ini, masyarakat dunia dapat saling berinteraksi satu sama lain tanpa dibatasi oleh gerak, ruang, dan waktu. Dalam konteks persaingan global yang semakin terbuka seperti sekarang ini, banyak tantangan yang harus dihadapi. Setiap negara harus bersaing dengan menonjolkan keunggulan sumber daya masing-masing.

Negara-negara yang unggul dalam sumber dayanya akan memenangkan persaingan. Sebaliknya negara-negara yang tidak memiliki keunggulan bersaing dalam sumber daya akan kalah dalam persaingan dan tidak akan mencapai banyak kemajuan, negara-negara yang memiliki keunggulan bersaing adalah negara yang dapat memperdayakan sumber daya ekonominya (conomic empowering) dan memberdayakan sumber daya manusianya (resources empowering) secara nyata. Sumber-sumber ekonomi dapat diberdayakan apabila sumber daya manusia memiliki keterampilan kreatif dan inovatif.

Masyarakat miskin adalah suatu kondisi dimana fisik masyarakat yang tidak memiliki akses ke prasarana dan sarana dasar lingkungan yang memadai, dengan kualitas perumahan dan pemukiman yang jauh di bawah standart kelayakan serta mata pencaharian yang tidak menentu yang mencakup seluruh multidimensi, yaitu dimensi politik, dimensi social, dimensi lingkungan, dimensi ekonomi dan dimensi asset.
Penggolongan kemiskinan didasarkan pada suatu standar tertentu yaitu dengan membandingkan tingkat pendapatan orang atau keluarga dengan tingkat pendapatan yang diperlukan untuk memenuhi kebutuhan pokok minimum. Berdasarkan criteria ini maka dikenal kemiskinan absolut dan kemiskinan relatif. Kemiskinan absolut adalah mereka yang tidak mampu memenuhi kebutuhan pokok minimum, sedangkan komunitas yang termasuk dalam kemiskinan relatif adalah mereka yang memiliki kemampuan untuk memenuhi kebutuhan pokok minimum tetapi secara relatif mereka masih di bawah rata-rata pendapatan masyarakat yang ada di sekitarnya.

Sedangkan diskursus lain mencoba mengetengahkan pembahasan kemiskinan yang dibedakan menjadi natural, kultural dan struktural. Kemiskinan natural sama pengertiannya dengan kemiskinan turun temurun, disebabkan oleh suatu kondisi keterbatasan secara alamiah yang dihadapi suatu komunitas sehingga sulit melakukan perubahan. Kemiskinan kultural adalah suatu kondisi miskin yang dihadapi komunitas, disebabkan oleh faktor budaya. Budaya yang hidup, diyakini dan dikembangkan dalam suatu masyarakat menyebabkan proses pelestarian kemiskinan dalam masyarakat itu sendiri.

Kemiskinan struktural merupakan suatu kemiskinan yang melanda suatu komunitas yang disebabkan oleh faktor-faktor tertentu yang dibangun manusia. Faktor-faktor tersebut muncul karena dibangun dan dikondisikan oleh manusia, sehingga menyebabkan kerugian pada suatu sisi. penyebab kemiskinan di Indonesia bukanlah 
kurangnya sumber daya alam, melainkan karena faktor non-alamiah, yaitu kesalahan dalam kebijakan ekonomi. Kemiskinan merupakan persoalan yang sangat kompleks, tidak semata-mata berhubungan dengan rendahnya pendapatan dan tingkat konsumsi masyarakat, namun berkaitan dengan rendahnya tingkat pendidikan, akses kesehatan, ketidakberdayaan untuk berpartisipasi dalam dalam proses pengambilan keputusan publik, ketidakmampuan menyampaikan aspirasi, serta berbagai masalah yang berkaitan dengan pembangunan manusia.

Untuk mengatasi berbagai persoalan bangsa khususnya dalam keterpurukan ekonomi bangsa ini membutuhkan orangorang yang memiliki jiwa wirausaha, yakni suatu semangat sikap mental positif yang mengutamakan kinerja dan produktifitas dalam mengoptimalkan pencapaian target. Oleh karena itu, semakin banyak anak bangsa yang memiliki jiwa wirausaha, semakin terbuka lapangan pekerjaan yang berdampak positif bagi pengurangan pengangguran dan peningkatan daya beli masyarakat. Masyarakat kecil dan menengah umumnya memiliki pemikiran bahwa modal merupakan hal segalanya dalam melakukan usaha. Hal ini menyebabkan kurang tertariknya masyarakat untuk membuka lapangan usaha, sehingga mereka lebih memilih pekerjaan formal baik di pemerintahan maupun swasta.

Wirausaha merupakan cara untuk memajukan Indonesia dengan prinsip berdikari maka akan memberikan keuntungan. Hal ini tentu akan menguntungkan karena akan membuka lapangan pekerjaan bagi masyarakat yang membutuhkan pekerjaan, selain itu dapat menguntungkan karena kreativitas yang dimiliki pelaku wirausaha itu mampu melihat peluang-peluang yang ada untuk mendapatkan keuntungan-keuntungan yang lebih. Melihat perkembangan di era globalisasi dan banyaknya pengangguran di Indonesia, PT Kereta Api Indonesia Daerah Oprasional 2 Bandung melakukan tanggung jawabnya sebagai perusahaan BUMN dengan melakukan program pemberdayaan masyarakat berupa pengembangan usaha kecil dan menengah. Kegiatan ini merupakan wujud tanggung jawab perusahaan demi meningkatkan perekonomian masyarakat.

Pemberdayaan masyarakat terjadi jika masyarakat saling menguatkan antar lingkungannya, membuat keterikatan sosial, dan membentuk komunitas sendiri untuk dapat menyelesaikan permasalahan mereka. jika sebenarnya yang dapat membangun suatu wilayahnya adalah masyarakat itu sendiri, mereka dapat melakukannya secara mandiri, namun tetap mereka membutuhkan suatu stimulus, seperti adanya training atau sosialisasi jadi mereka tau apa yang dapat mereka lakukan untuk mengembangkan potensi dan mengatasi masalah yang ada di lingkungan mereka sendiri.

Pemberdayaan sebagai strategi pengentasan kemiskinan harus menjadi proses multidimensi dan multisegi yang memobilisasi sumberdaya dan kapasitas masyasrakat. Dalam hal ini, pemberdayaan tidak lagi menjadi sesuatu yang teoritis melainkan menjadi alat untuk memutar-balikkan proses pemiskinan. pemberdayaan masyarakat merupakan sebuah konsep pembangunan ekonomi yang merangkum nilai-nilai sosial. konsep ini mencerminkan paradigma baru pembangunan, yakni yang bersifat "peoplecentered, participatory, empowering, and sustainable

Program kemitraan ini merupakan bagian dari CSR PT. Kereta Api Indonesia untuk meningkatkan kesejahteraan masyarakat, dengan berbasis mencintai produk-produk dalam negri dengan mengembangkan kreativitas-kreativitas masyarakat. Bandung terkenal dengan orangorangnya yang kreatif, oleh karena itu dibutuhkan partisipasi masyarakat dalam program ini guna memajukan perekonomian dan kesejahteraan masyarakat menengah kebawah serta memperkenalkan kebudayaan dan potensi- potensi yang ada. 
Sementara itu, keterbatasan wawasan, kurangnya ketrampilan, kesehatan yang buruk, serta etos kerja yang rendah, semuanya merupakan faktor internal. Faktor-faktor internal dapat dipicu munculnya oleh faktorfaktor eksternal juga. Kesehatan masyarakat yang buruk adalah pertanda rendahnya gizi masyarakat. Rendahnya gizi masyarakat adalah akibat dari rendahnya pendapatan dan terbatasnya sumber daya alam. Selanjutnya, rendahnya penguasaan ilmu pengetahuan dan teknologi (iptek) adalah akibat dari kurangnya pendidikan. Hal yang terakhir ini juga pada gilirannya merupakan akibat dari kurangnya pendapatan. Kurangnya pendapatan merupakan akibat langsung dari keterbatasan lapangan kerja. Dan seterusnya begitu, berputar-putar dalam proses saling terkait.

Pengembangan usaha biasa dilakukan dengan beberapa teknik, salah satunya yaitu melalui perluasan cakupan usaha. Tulisan ini akan menjelaskan mengenai teknik pengembangan usaha melalui perluasan cakupan usaha. Pengembangan usaha adalah tugas dan proses persiapan analitis tentang peluang pertumbuhan potensial, dukungan dan pemantauan pelaksanaan peluang pertumbuhan usaha, tetapi tidak termasuk keputusan tentang strategi dan implementasi dari peluang pertumbuhan usaha.

Perkembangan usaha adalah suatu bentuk usaha kepada usaha itu sendiri agar dapat berkembang menjadi lebih baik lagi dan agar mencapai pada satu titik atau puncak menuju kesuksesan. Perkembangan usaha di lakukan oleh usaha yang sudah mulai terproses dan terlihat ada kemungkinan untuk lebih maju lagi.

Perkembangan usaha adalah perdagangan yang dilakukan oleh sekelompok orang yg terorganisasi untuk mendapatkan laba dengan memproduksi dan menjual barang atau jasa untuk memenuhi kebutuhan konsumen. Namun menurut Kuncoro (2007) ada empat karakteristik yang biasanya dimiliki oleh kebanyakan UMKM di Indonesia.
Pertama, tidak adanya pembagian tugas yang jelas antara bidang administrasi dan operasi. Kebanyakan industri kecil dikelola oleh perorangan yang merangkap sebagai pemilik sekaligus pengelola perusahaan yang memanfaatkan tenaga kerja dari keluarga dan kerabat dekatnya. Kedua, rendahnya akses terhadap lembaga-lembaga kredit formal sehingga mereka cenderung menggantungkan pembiayaan usahanya dari modal sendiri atau sumber-sumber lain seperti keluarga, kerabat, pedagang, perantara, bahkan rentenir. Ketiga, sebagian besar usaha ini belum memiliki status badan hukum. Keempat, hampir sepertiga UMKM bergerak pada kelompok usaha makanan, minuman, dan tembakau, barang galian bukan logam, tekstil, dan industri kayu, bambu, rotan, rumput, dan sejenisnya termasuk perabot rumah tangga.

Pemberdayaan usaha mikro, kecil dan menengah (UMKM) merupakan langkah yang strategis dalam meningkatkan dan memperkuat dasar kehidupan perekonomian dari sebagian terbesar rakyat Indonesia, khususnya melalui penyediaan lapangan kerja dan mengurangi kesenjangan dan tingkat kemiskinan.

Pada level produk pengembangan usaha berarti mengembangkan produk atau teknologi baru. Meskipun tingkat pengembangan dapat berbeda dari perusahaan ke perusahaan. Tingkat perkembangan usaha dibagi menjadi satu kategori yaitu, perkembangan incremental. Perkembangan Incremental adalah perkembangan yang meningkatkan fungsi yang ada platform atau teknologi, sementara pengembangan mengganggu atau terputus-putus benar-benar hal baru yang dikembangkan dari awal.

Pengembangan usaha di tingkat komersial berarti berburu pelanggan baru di segmen pasar yang baru. Dengan demikian pekerjaan ini memerlukan individu secara psikologis yang kuat dan yang sangat didorong mampu menangani banyak masalah. 


\section{HASIL DAN PEMBAHASAN}

Tingkat berikutnya dari pengembangan usaha komersial adalah saluran atau setup organisasi penjualan. Saluran atau organisasi penjualan dapat terdiri dari mitra, agen seperti, distributor, pemegang lisensi, franchisee, atau cabang anda sendiri nasional atau internasional. Tingkat pengembangan usaha komersial adalah tingkat rantai nilai. Pada pengembangan rantai nilai tingkat usaha adalah tentang mengembangkan penawaran produk secara keseluruhan.

Bila organisasi harus memutuskan apakah akan membuat atau membeli kompetensi organisasi tertentu Kita memasuki bidang pengembangan bisnis perusahaan . Fokusnya adalah bukan pada produk maupun komersial tingkat tetapi pada korporasi tingkatan usaha. Intinya tingkat pengembangan usaha ini adalah tentang merger \& akuisisi ( $\mathrm{M} \& \mathrm{~A}$ ), usaha patungan (JV), saham langsung investasi (DEI) dan aliansi strategis. Ini berkaitan dengan analisa bisnis portofolio, keuangan perusahaan, hukum kontrak, hukum pajak, hukum sosial, anti kepercayaan hukum, manajemen perubahan, dan manajemen budaya.

Menurut Keputusan Menteri Keuangan No.40/KMK.06/2003 tanggal 29 Januari 2003, Usaha mikro yaitu usaha produktif milik keluarga atau perorangan Warga Negara Indonesia dan memiliki hasil penjualan paling banyak Rp.100.000.000,00 (seratus juta rupiah) per tahun. Usaha Mikro dapat mengajukan kredit kepada bank paling banyak Rp.50.000.000,--

Sebagaimana dimaksud Undang-undang No.9 Tahun 1995, Usaha kecil adalah usaha produktif yang berskala kecil dan memenuhi kriteria kekayaan bersih paling banyak Rp200.000.000,00 (dua ratus juta rupiah) tidak termasuk tanah dan bangunan tempat usaha atau memiliki hasil penjualan paling banyak Rp1.000.000.000,00 (satu milyar rupiah) per tahun serta dapat menerima kredit dari bank maksimal di atas Rp50.000.000,- (lima puluh juta rupiah) sampai dengan Rp.500.000.000,(lima ratus juta rupiah).

Usaha Menengah sebagaimana dimaksud Inpres No.10 tahun 1998 adalah usaha bersifat produktif yang memenuhi kriteria kekayaan usaha bersih lebih besar dari Rp200.000.000,00 (dua ratus juta rupiah) sampai dengan paling banyak sebesar Rp10.000.000.000,00, (sepuluh milyar rupiah) tidak termasuk tanah dan bangunan tempat usaha serta dapat menerima kredit dari bank sebesar Rp.500.000.000,00 (lima ratus juta rupiah) s/d Rp.5.000.000.000,00 (lima milyar rupiah).

Usaha Mikro adalah usaha produktif milik orang perorangan dan/atau badan usaha perorangan yang memenuhi kriteria Usaha Mikro sebagaimana diatur dalam UndangUndang ini. Usaha Kecil adalah usaha ekonomi produktif yang berdiri sendiri, yang dilakukan oleh orang perorangan atau badan usaha yang bukan merupakan anak perusahaan atau bukan cabang perusahaan yang dimiliki, dikuasai, atau menjadi bagian baik langsung maupun tidak langsung dari usaha menengah atau usaha besar yang memenuhi kriteria Usaha Kecil sebagaimana dimaksud dalam Undang-Undang ini.

Usaha Menengah adalah usaha ekonomi produktif yang berdiri sendiri, yang dilakukan oleh orang perseorangan atau badan usaha yang bukan merupakan anak perusahaan atau cabang perusahaan yang dimiliki, dikuasai, atau menjadi bagian baik langsung maupun tidak langsung dengan Usaha Kecil atau usaha besar dengan jumlah kekayaan bersih atau hasil penjualan tahunan.

Usaha mikro, kecil, dan menengah dalam perekonomian suatu negara memiliki peran yang penting. Bukan hanya di Indonesia, tetapi kenyataan menunjukkan bahwa posisi usaha mikro, kecil, dan menengah mempunyai peranan strategis di negara-negara lain juga. Indikasi yang menunjukkan peranan usaha mikro, kecil, dan menengah itu dapat dilihat dari kontribusinya terhadap PDB, Eksport nonmigas, penyerapan tenaga kerja, dan 
peningkatan kualitas sumber daya manusia yang cukup berarti.

Adapun peranan yang sangat strategis dan penting ditinjau dari berbagai aspek. Pertama, jumlah industrinya yang besar dan terdapat dalam setiap sektor ekonomi. Kedua, potensinya yang besar dalam menciptakan lebih banyak kesempatan kerja bila dibandingkan dengan investasi yang sama pada usaha dengan skala lebih besar. Ketiga, kontribusi UMKM dalam pembentukkan PDB cukup signifikan. Keempat, memiliki sumbangan kepada devisa negara dengan nilai ekspor yang cukup stabil.

Keberhasilan untuk bertahan dalam masa krisis tidak serta merta menjadikan UMKM mampu berkembang dengan baik. Banyak faktor yang mempengaruhi lambannya perkembangan usaha tersebut, antara lain perhatian dari pemerintah dan kalangan perbankan yang dirasakan masih kurang.

Walaupun upaya-upaya untuk meningkatkan perhatian kepada UMKM sudah dilakukan, masih banyak pekerjaan rumah yang belum terselesaikan secara optimal. Pekerjaan rumah tersebut antara lain adalah upaya pembinaan, pengembangan dan juga pendanaan (modal) kepada sektor UMKM. Sementara modal memang penting, tetapi dalam mewujudkan komitmennya pemerintah baru pun harus terpusat pada rencana nasional. Masalahnya bahwa belum ada kejelasan kebijakan industri dan bagaimana yang diadopsi nanti agar lebih mampu mempercepat pertumbuhan ekonomi dan penciptaan lapangan kerja bagi penggangguran dan mengatasi kemiskinan.

Survey dari BPS mengidentifikasikan berbagai kelemahan dan permasalahan yang dihadapi UMKM berdasarkan prioritasnya, yakni meliputi:

- Kurangnya permodalan

- Kesulitan dalam pemasaran

- Persaingan usaha yang ketat

- Kesulitan bahan baku, (v) kurang teknis produksi dan keahlian
- Kurangnya keterampilan manajerial (SDM)

Kurangnya pengetahuan dalam masalah manajemen termasuk dalam keuangan dan akuntansi. Selain itu, UMKM juga membutuhkan adanya iklim usaha yang kondusif seperti adanya kemudahan dalam hal perijinan, perundangan yang memadai dan kondisi makro ekonomi yang stabil.

Hasil kajian tersebut mengindikasikan bahwa salah satu faktor dominan dalam pengembangan UMKM adalah faktor permodalan, meskipun bukan yang paling menentukan dalam pertumbuhan dan perkembangan UMKM.

Kelompok masyarakat miskin amat rentan karena mereka tidak memiliki sistem penyangga kehidupan yang memadai. Kebutuhan kecil dipenuhi dengan cara menggunakan uangnya yang sangat terbatas jumlahnya, mengurangi konsumsi, barter, pinjam dari teman dan pedagang. Mereka juga mengalami ketidakberdayaan yang ditandai dengan diabaikannya mereka oleh hukum, ketiadaan bantuan hukum bagi mereka, kalah dalam kompetisi mencari kerja dan mereka pun tidak memperoleh pelayanan publik yang optimal.Pemberdayaan ini dapat dijadikan sebagai media dalam menyuarakan kepentingan, prioritas dan alternatif terhadap solusi yang berkaitan dengan masalah, sehingga dalam prosesnya terdapat partisipasi oleh warganya.

Proses partisipasi ini bertujuan mendevolusi kekuasaan pada komunitas sehingga insklusivitas dapat dtingkatkan dalam proses pengambilan sebuah keputusan.Konsep pemberdayaan pun hadir dari berbagai para ahli, diantaranya Jim Ife (1995), Deepa Narayan (et.al., 2002) dan juga Paulo Freire (1972). Jim Ife mendefinisikan pemberdayaan sebagai upaya memberikan sumber daya, kesempatan, pengetahuan dan keterampilan kepada warga untuk meningkatkan kemampuan mereka dalam menentukan masa depannya sendiri dan 
partisipasi dalam dan memenuhi kehidupan komunitasnya. Selanjutnya, Deepa Narayan memberikan pengertian pemberdayaan yang memiliki makna perluasan aset-aset dan kemampuan masyarakat yang tidak berdaya (miskin) menegosiasikan dengan mempengaruhi, mengontrol serta mengendalikan tanggung jawab lembagalembaga memengaruhi kehidupannya. Pemberdayaan sama dengan konsientisasi (conscientization), yang merupakan suatu proses pemahaman dan penumbuhan kesadaran terhadap situasi yang sedang terjadi (relasi politik, ekonomi, dan sosial) atau kesadaran kritis.

Dalam hal ini, proses pemberdayaan diawali dengan memahami karakteristik masyarakat lokalnya, termasuk didalmnya yaitu ada atau tidaknya sebuah perbedaan antara satu komunitas dengan komunitas lain. Setelah itu, dalam proses pemberdayaan harus memperoleh dukungan dari pimpinan, tokohtokoh masyarakat setempat. Lalu, selanjutnya dapat melakukan pendekatan secara persuasif, agar masyarakatnya sadar bahwa mereka punya masalah yang perlu dipecahkan dan juga kebutuhan yang perlu dipenuhi.

Sesusai melakukan pendekatan secara persuasif terhadap masyarakat, maka kita bersama masyarakat dapat melakukan sebuah analisis masalah dan merumuskan pemecahannya secara bersama-sama. Tidak hanya itu saja, kita mampu mengidentifikasi permasalahan prioritas. Setelah tahap identifikasi, kita dapat membangun rasa percaya diri masyarakat dan meningkatkan kemampuan masyarakat dalam menetapkan program dengan segala prioritas. Berdasarkan upaya tersebut maka, kita semakin membuat masyarakat tahu dan mengerti bahwa mereka memiliki kekuatan-kekuatan dan sumbersumber yang dapat dimobilisasi untuk pemecahan masalah dan memenuhi kebutuhannya. Setelah mereka sadar, maka kita bersama masyarakat dapat menciptakan program secara berkesinambungan dan berkelanjutan serta menumbuhkan kemandirian masyarakat. Pada proses pemberdayaan, terdapat dimensi dan level pemberdayaan. Secara perspektif dimensi, pemberdayaan memiliki 2 ranah yaitu personal dan masyarakat.

Partisipasi masyarakat ini dilihat sebagai perubahan relasi subyek-obyek yang ada, antara pemerintah dan institusi lainnya dengan komunitas. Prosenya adalah dengan cara merubah cara pandang para praktisi pembangunan dengan menstranformasikan kepentingan kepentingan kelas mereka dan melibatkan komunitas dalam proses partisipatif. Proses partisipasi masyarakat dalam pengembangan masyarakat memerlukan waktu yang lama dan komitmen jangka panjang dari berbagai stakeholders, dan juga dalam parisipasi tersebut memiliki makna yang berbeda pada konteks yang berbeda. Partisipasi dalam pemberdayaan masyarakat pun memiliki makna dengan 3 asumsi yaitu, program pemerintah dan respon masyarakat yang menghasilkan partisipasi, begitu juga sebaliknya, dan juga 3 subjek menjadi sejajar dan saling bersinergi sehingga, dari ketiganya membentuk sebuah partisipasi aktif.

\section{SIMPULAN}

Dengan dilakukannya pemberdayaan UMKM dapat memberikan peranan yang sangat strategis dan penting ditinjau dari berbagai aspek. Pertama, jumlah industrinya yang besar dan terdapat dalam setiap sektor ekonomi. Kedua, potensinya yang besar dalam menciptakan lebih banyak kesempatan kerja bila dibandingkan dengan investasi yang sama pada usaha dengan skala lebih besar. Ketiga, kontribusi UMKM dalam pembentukkan PDB cukup signifikan. Keempat, memiliki sumbangan kepada devisa negara dengan nilai ekspor yang cukup stabil. Keberhasilan untuk bertahan dalam masa krisis tidak serta merta menjadikan UMKM mampu berkembang dengan baik. Banyak faktor yang mempengaruhi lambannya perkembangan usaha tersebut, antara lain perhatian dari pemerintah dan kalangan perbankan yang dirasakan masih kurang. 
UKM juga memberikan dampak positif yang sangat menjanjikan khususnya bagi para pelaku ekonomi yang sukses yang mengawali usahanya dari UKM. Saat ini, UKM hampir sebagian besar menguasai sektor usaha Indonesia. Oleh karena itu, untuk mengembangkan UKM pemerintah perlu melindungi UKM agar dapat bersaing secara sehat dengan usaha ekonomi lain yang lebih besar.

Dan telah kita ketahui juga bahwa ketika masa krisis moneter perusahaan-perusahaan besar mengalami collapse, UKM masih mampu bertahan menghadapi krisis tersebut, sehingga UKM perlu mendapatkan perhatian khusus dari pemerintah untuk lebih dikembangkan. Pada tahun 2020 yang akan datang adalah tahun yang memberikan banyak peluang untuk UKM.

UKM dapat mewujudkan impian para pemimpin ASEAN suatu komunitas ekonomi ASEAN yang tertuang dalam Bali Concord II, yaitu peredaran produk-produk barang dan jasa tidak lagi dibatasi batas negara.

\section{REKOMENDASI}

Beberapa rekomendasi kebijakan dalam program kemitraan pengembangan UMKM ini

1. Perlu adanya ke berelanjutan program ini, karena program ini dapat berguna untuk pemecahan kemiskinan
2. Adanya pengawasan agar program ini tidak hanya ada sebagai syarat perusahaan mengenai program csrnya tapi harus ada tanggung jawab perusahaan terhadap masyarakat.

3. Harus mencari pekerja sosial professional dalam kegiatan CSR, karena pekerja sosial lebih paham dan dapat mengerti keadaan sekitar.

\section{DAFTAR PUSTAKA}

http://www.ginandjar.com/public/04StrategiP engembanganUkm.pdf

http://www.bps.go.id/Subjek/view/id/35\#subj ekViewTab1|accordion-daftar$\underline{\text { subjek2 }}$

digilib.unila.ac.id/552/8/Maifori\%20 Watiah_Bab\%20II.pdf

Kuncoro, Mudrajad. 2007. Ekonomika Industri Indonesia : Menuju Negara Industri Baru 2030?. Yogyakarta. Andi

Hikmat, harry. 2004. Strategi Pemberdayaan Masyarakat. Bandung. Humaniora Utama Press.

Natsir, Muhammad. 2005. Metode Penelitian. Jakarta. Ghalia Indonesia.

Suharto, Edi. 2007. Kebijakan Sosial Sebagai Kebijakan Publik. Bandung. Alfabeta 